\title{
A turiasaurian sauropod dinosaur from the Early Cretaceous Wealden Supergroup of the United Kingdom
}

\author{
Philip D Mannion ${ }^{\text {Corresp. } 1}$ \\ ${ }^{1}$ Department of Earth Science and Engineering, Imperial College London, London, United Kingdom \\ Corresponding Author: Philip D Mannion \\ Email address: p.mannion@imperial.ac.uk
}

The Jurassic/Cretaceous $(\mathrm{J} / \mathrm{K})$ boundary, 145 million years ago, has long been recognised as an extinction event or faunal turnover for sauropod dinosaurs, with many 'basal' lineages disappearing. However, recently, a number of 'extinct' groups have been recognised in the Early Cretaceous, including diplodocids in Gondwana, and non-titanosauriform macronarians in Laurasia. Turiasauria, a clade of non-neosauropod eusauropods, was originally thought to have been restricted to the Late Jurassic of western Europe. However, its distribution has recently been extended to the Late Jurassic of Tanzania (Tendaguria tanzaniensis), as well as to the Early Cretaceous of the USA (Mierasaurus bobyoungi and Moabosaurus utahensis), demonstrating the survival of another 'basal' clade across the $\mathrm{J} / \mathrm{K}$ boundary. Teeth from the Middle Jurassic-Early Cretaceous of western Europe and North Africa have also tentatively been attributed to turiasaurs, whilst recent phylogenetic analyses recovered Late Jurassic taxa from Argentina and China as further members of Turiasauria. Here, an anterior dorsal centrum and neural arch (both NHMUK 1871) from the Early Cretaceous Wealden Supergroup of the UK are described for the first time. NHMUK 1871 shares several synapomorphies with Turiasauria, especially the turiasaurs Moabosaurus and Tendaguria, including: (1) a strongly dorsoventrally compressed centrum; (2) the retention of prominent epipophyses; and (3) an extremely low, non-bifid neural spine. NHMUK 1871 therefore represents the first postcranial evidence for Turiasauria from European deposits of unequivocal Early Cretaceous age. Although turiasaurs show clear heterodont dentition, only broad, characteristically 'heart'-shaped teeth can currently be attributed to Turiasauria with confidence. As such, several putative turiasaur occurrences based on isolated teeth from Europe, as well as the Middle Jurassic and Early Cretaceous of Africa, cannot be confidently referred to Turiasauria. Unequivocal evidence for turiasaurs is therefore restricted to the late Middle Jurassic-Early Cretaceous of western Europe, the Late Jurassic of Tanzania, and the late Early Cretaceous of the USA, although remains from elsewhere might ultimately demonstrate that the group had a nearglobal distribution. 


\title{
A turiasaurian sauropod dinosaur from the Early Cretaceous Wealden Supergroup of the United Kingdom
}

\author{
Philip D. Mannion
}

Department of Earth Science and Engineering, Imperial College London, South Kensington Campus, London, SW7 2AZ, UK (Email: philipdmannion@gmail.com)

RRH: EARLY CRETACEOUS UK TURIASAUR

LRH: P. D. MANNION

\section{ABSTRACT}

The Jurassic/Cretaceous (J/K) boundary, 145 million years ago, has long been recognised as an extinction event or faunal turnover for sauropod dinosaurs, with many 'basal' lineages disappearing. However, recently, a number of 'extinct' groups have been recognised in the Early Cretaceous, including diplodocids in Gondwana, and non-titanosauriform macronarians in Laurasia. Turiasauria, a clade of non-neosauropod eusauropods, was originally thought to have been restricted to the Late Jurassic of western Europe. However, its distribution has recently been extended to the Late Jurassic of Tanzania (Tendaguria tanzaniensis), as well as to the Early Cretaceous of the USA (Mierasaurus bobyoungi and Moabosaurus utahensis), demonstrating the survival of another 'basal' clade across the J/K boundary. Teeth from the Middle JurassicEarly Cretaceous of western Europe and North Africa have also tentatively been attributed to turiasaurs, whilst recent phylogenetic analyses recovered Late Jurassic taxa from Argentina and China as further members of Turiasauria. Here, an anterior dorsal centrum and neural arch (both NHMUK 1871) from the Early Cretaceous Wealden Supergroup of the UK are described for the first time. NHMUK 1871 shares several synapomorphies with Turiasauria, especially the turiasaurs Moabosaurus and Tendaguria, including: (1) a strongly dorsoventrally compressed centrum; (2) the retention of prominent epipophyses; and (3) an extremely low, non-bifid neural spine. NHMUK 1871 therefore represents the first postcranial evidence for Turiasauria from European deposits of unequivocal Early Cretaceous age. Although turiasaurs show clear heterodont dentition, only broad, characteristically 'heart'-shaped teeth can currently be attributed to Turiasauria with confidence. As such, several putative turiasaur occurrences based on isolated teeth from Europe, as well as the Middle Jurassic and Early Cretaceous of Africa, cannot be confidently referred to Turiasauria. Unequivocal evidence for turiasaurs is therefore restricted to the late Middle Jurassic-Early Cretaceous of western Europe, the Late Jurassic of Tanzania, and the late Early Cretaceous of the USA, although remains from elsewhere might ultimately demonstrate that the group had a near-global distribution.

\section{INTRODUCTION}

The Late Jurassic is often regarded as a period of heightened sauropod dinosaur diversity, prior to a precipitous decline across the Jurassic/Cretaceous $(\mathrm{J} / \mathrm{K})$ boundary (145 million years ago), at which point many 'basal' sauropod lineages went extinct (Bakker, 1977; Hunt et al., 
1994; Wilson \& Sereno, 1998; Upchurch \& Barrett, 2005; Barrett, McGowan \& Page, 2009; Mannion et al., 2011). Increasingly, however, it is becoming apparent that any $\mathrm{J} / \mathrm{K}$ extinction was not instantaneous (Tennant et al., 2017), at least for sauropods, with representatives of several 'extinct' sauropod groups now recognised from Early Cretaceous deposits (Gallina et al., 2014; Royo-Torres et al., 2014, 2017a,b; Upchurch, Mannion \& Taylor, 2015; D’Emic \& Foster, 2016; McPhee et al., 2016).

The non-neosauropod eusauropod clade Turiasauria was first recognised by Royo-Torres, Cobos \& Alcalá (2006) for three genera (Turiasaurus riodevensis, Losillasaurus giganteus, Galveosaurus herreroi) from the Late Jurassic of Spain (see Campos-Soto et al. [2017] regarding this revised age). Although Galveosaurus has subsequently been demonstrated to more likely represent a macronarian neosauropod (e.g. Barco, Canudo \& Cuenca-Bescós, 2006; Carballido et al., 2011; D'Emic, 2012; Mannion et al., 2013), the western European record of named turiasaurs has since been expanded to include the Late Jurassic Portuguese taxon Zby atlanticus (Mateus, Mannion \& Upchurch, 2014). In addition to postcranial remains, both Turiasaurus and Zby preserve teeth. These tooth crowns are mesiodistally broad relative to their apicobasal length, and have a distinctive 'heart'-shaped outline (Royo-Torres, Cobos \& Alcalá, 2006), narrowing mesiodistally along their apical halves (Mateus, Mannion \& Upchurch, 2014). Primarily consisting of isolated teeth, additional remains have been referred to Turiasauria from contemporaneous Iberian deposits (Royo-Torres, Cobos \& Alcalá, 2006; Royo-Torres et al., 2009; Mocho et al., 2016). Several authors have suggested that 'heart'-shaped teeth from the Middle Jurassic-Early Cretaceous of the UK and France might also be attributable to turiasaurs, including the type specimens of 'Cardiodon rugulosus', 'Neosodon', and 'Oplosaurus armatus' (Royo-Torres, Cobos \& Alcalá, 2006; Néraudeau et al., 2012; Royo-Torres \& Upchurch, 2012; Mocho et al., 2016).

The distribution of turiasaurs was recently expanded to include the Early Cretaceous of the western USA (Royo-Torres et al., 2017a), based on relatively complete skeletons of two taxa, Mierasaurus bobyoungi (Royo-Torres et al., 2017a) and Moabosaurus utahensis (Britt et al., 2017), and thus confirming the group's survival across the J/K boundary (Royo-Torres et al., 2017a). Finally, several remains from Africa have been suggested to represent turiasaurs. Mocho et al. (2016) commented upon similarities of two fragmentary Middle Jurassic teeth from Madagascar and Morocco, as well as a partial tooth from the Early Cretaceous of Libya, with European turiasaurs. Xing et al. (2015) also recovered the Middle Jurassic Moroccan sauropod Atlasaurus imelakei in a polytomy with Losillasaurus and Turiasaurus. Royo-Torres \& Cobos (2009) suggested that several postcranial remains from the Late Jurassic Tendaguru Formation of Tanzania might also belong to Turiasauria. Most recently, Mannion et al. (in press) presented new anatomical data (see also Britt et al., 2017: p. 236) and phylogenetic analyses linking the enigmatic Tendaguru sauropod Tendaguria tanzaniensis with the turiasaur Moabosaurus. These authors recovered additional Late Jurassic taxa as possible turiasaurs: in some of their analyses, the Tendaguru sauropod Janenschia robusta and the Argentinean taxon Tehuelchesaurus benitezii were also placed in Turiasauria, whilst the Chinese sauropod Bellusaurus sui was consistently positioned as a turiasaur too.

Here, a previously undescribed anterior dorsal vertebra (NHMUK 1871) of a turiasaur from the Early Cretaceous Wealden Supergroup of the UK is presented. The putative turiasaurian 
92

93

94

95

96

97

98

99

100

101

102

103

104

105

106

107

108

109

110

111

112

113

114

115

116

117

118

119

120

121

122

123

124

125

126

127

128

129

130

131

affinities of several African and European occurrences are also discussed, including the utility of tooth morphology for identifying turiasaurs.

\section{HISTORY AND PROVENANCE OF NHMUK 1871}

NHMUK 1871 is a relatively complete, but poorly preserved, anterior dorsal centrum and neural arch from an unknown Early Cretaceous 'Wealden' locality of the UK. Purchased by the NHMUK in 1891 as part of the Samuel H. Beckles collection, this specimen does not seem to have ever been mentioned in the published literature. Correspondence between Beckles and the NHMUK also does not provide any information on the provenance of NHMUK 1871. Most of the dinosaur specimens collected by Beckles (e.g. the sauropod Haestasaurus ['Pelorosaurus'] becklesii [Upchurch, Mannion \& Taylor, 2015]) came from the late Berriasian-Valanginian Hastings Group, in Hastings, East Sussex, southeastern England (Woodhams, 1990), and so this is the most likely source of NHMUK 1871. However, Beckles also collected material from elsewhere in the southeast of England, including the Isle of Wight (Woodhams, 1990), and so the specimen could conceivably have come from another Wealden locality. It also remains possible that NHMUK 1871 came from a slightly older stratigraphic unit, given that Beckles also collected fossil remains from the Berriasian section of the Purbeck Group (Owen, 1854), although the reported provenance of 'Wealden' suggests that this was probably not the case. Stratigraphically older and younger units in the areas in which Beckles collected were deposited under marine environments, and thus are also unlikely to have yielded NHMUK 1871. As such, although NHMUK 1871 is most likely to be late Berriasian-Valanginian, this cannot be conclusively demonstrated. Given the above discussion, it seems that the specimen can be attributed to the Wealden Supergroup, but it could conceivably have come from any section. Thus, the stratigraphic age of NHMUK 1871 can only be constrained to late Berriasian-early Aptian (Batten, 2011).

NHMUK 1871 comprises a centrum (including neural arch pedicels) and an unfused neural arch (Figs 1,2). Although the two elements are a close match in size, it is not possible to rearticulate the centrum and neural arch, and this also results in an unusually dorsoventrally elongate neural canal. As such, it seems probable that they do not belong to the same vertebra. Both appear to be from the anterior region of the dorsal vertebral series though, and they probably represent approximately the second and third dorsal vertebrae. One further note of caution pertains to their preservation: whereas the neural arch is primarily black in colour, only a few small areas of the centrum display a similar colour. As such, although the available information indicates that they came from the same locality, and their relative sizes are consistent with being from the same individual, it is possible that the centrum and neural arch come from separate beds.

\section{Institutional Abbreviations}

NHMUK, Natural History Museum, London, UK

\section{SYSTEMATIC PALAEONTOLOGY}


132 Sauropoda Marsh, 1878

133 Eusauropoda Upchurch, 1995

134 Turiasauria Royo-Torres, Cobos \& Alcalá, 2006

135 Turiasauria indet.

136

Material: NHMUK 1871, a relatively complete, but poorly preserved, anterior dorsal centrum (Fig. 1) and separate neural arch (Fig. 2).

139

Locality and stratigraphic position: Unknown locality, southeastern England, United Kingdom; probably from the Wealden Supergroup; late Berriasian-early Aptian (Early Cretaceous).

142

\section{DESCRIPTION}

144

The centrum is poorly preserved and incomplete, especially around the ventrolateral margins of its posterior cotyle (Fig. 1; see Table 1 for measurements). It is strongly opisthocoelous, and much wider mediolaterally than it is dorsoventrally tall (ratio $=1.44$ ). The ventral surface is transversely convex, lacking ridges or excavations. Each lateral surface is too poorly preserved to determine whether the parapophyses were situated on the centrum or on the neural arch pedicels, although they are definitely absent from the preserved neural arch. Based on the right side of the centrum, a lateral pneumatic foramen is present (Fig. 1), but poor preservation and infilling by matrix mean that little of its morphology can be discerned. There is evidence for several poorly preserved laminae, comprising the anterior centrodiapophyseal lamina $(A C D L)$, posterior centrodiapophyseal lamina ( $P C D L)$, centroprezygapophyseal lamina (CPRL), and centropostzygapophyseal lamina (CPOL) (Fig. 1). The neural arch pedicels terminate a short distance from the posterior margin of the centrum. The lack of fusion of both the centrum and neural arch with the rest of its respective vertebra indicates that this individual was not fully grown at the time of death.

Erosion of the centrum in places reveals that it was pneumatised, with rounded camerae of $\sim 15 \mathrm{~mm}$ in diameter. No evidence for pneumaticity is visible in the neural arch. Unfortunately, attempts to CT scan the vertebra, to examine its internal tissue structure, were unsuccessful, as a result of its high density. As such, we cannot be sure whether the centrum was pneumatised by small camerae throughout, or if these were primarily restricted to near the outer bone surface.

In general, the neural arch is better preserved than the centrum (Fig. 2; see Table 1 for measurements). The flat articular surfaces of the widely separated prezygapophyses face dorsomedially and slightly anteriorly. They also expand anteroposteriorly towards their lateral tips. There is evidence for a V-shaped interprezygapophyseal lamina (TPRL), but this has been largely worn away (Fig. 2). The postzygapophyses are situated more dorsally than the prezygapophyses, and their articular surfaces face ventrolaterally and posteriorly. Overall, the zygapophyseal table is oriented at approximately $40^{\circ}$ to the horizontal. There is no hyposphene, which is consistent with this being an anterior dorsal vertebra, and the postzygapophyses are connected by a horizontal interpostzygapophyseal lamina (TPOL). A prominent epipophysis is present on the dorsal surface of each postzygapophysis (Fig. 2). 
175 The diapophyses project laterally and slightly ventrally, and there is evidence for a poorly preserved PCDL. The anterior and posterior surfaces of the diapophyses are unexcavated. A poorly preserved, near-horizontal postzygodiapophyseal lamina (PODL) is present. A shallow, dorsally-facing, elliptical spinodiapophyseal fossa (SDF) is situated anterior to the PODL, bounded anteriorly by the spinoprezygapophyseal lamina (SPRL) (Fig. 2).

SPRLs run dorsomedially from the middle of the posterior margin of the prezygapophyses. The anterior surface of the neural spine is transversely concave between the two SPRLs, and becomes rugose towards the midline, although there is no clearly defined prespinal ridge. The posterior surface of the neural spine is transversely concave, but poor preservation obscures whether a postspinal ridge or rugosity was present. Dorsomedially oriented, undivided spinopostzygapophyseal laminae (SPOLS) contribute to the posterolateral margins of the neural spine, but there are no spinodiapophyseal laminae (SPDLs). The dorsoventrally low, unbifurcated neural spine projects only very slightly above the level of the postzygapophyses, and is anteroposteriorly narrow, especially towards the midline (Fig. 2).

\section{DISCUSSION}

\section{Taxonomic affinities of NHMUK 1871}

To determine the taxonomic affinities of NHMUK 1871, it is compared with anteriormost dorsal vertebrae from an array of eusauropods (see Fig. 3). A strongly dorsoventrally compressed centrum (mediolateral width to dorsoventral height ratio of $>1.3$ ) characterises the anterior dorsal vertebrae of several somphospondylan titanosauriforms (Mannion et al., 2013), the basal macronarian Lourinhasaurus (Mocho et al., 2014), Apatosaurus (Gilmore, 1936), and Turiasauria (Royo-Torres et al., 2017a; Mannion et al., in press). The presence of camerae in the centrum is consistent with the anteriormost dorsal vertebrae of most eusauropods more derived than Omeisaurus, whereas the absence of clear camellae suggests that NHMUK 1871 lies outside of Titanosauriformes, and that it is not a mamenchisaurid (Wedel, 2003, 2005).

The steeply inclined zygapophyseal table of NHMUK 1871 is most similar to the morphology in the anterior dorsal vertebrate of titanosaurs and rebbachisaurids, contrasting with the more shallowly oriented tables of other sauropods, including turiasaurs (Carballido et al., 2012; Poropat et al., 2016). Whereas the cervical vertebrae of most sauropods are characterised by the presence of epipophyses (Yates, 2007; Wilson \& Upchurch, 2009; Mannion et al., 2013), their retention in anterior dorsal vertebrae is much less common, where they tend to be reduced structures (Mannion et al., in press). However, NHMUK 1871 shares the presence of prominent epipophyses with the turiasaurs Moabosaurus and Tendaguria, as well as Jobaria (Mannion et al., in press). Epipophyses are absent in other turiasaurs in which anteriormost dorsal vertebrae are preserved, i.e. Mierasaurus and Turiasaurus (Royo-Torres et al., 2006, 2017a; Mannion et al., in press). Only a small number of sauropod taxa are characterised by such a low neural spine in their anterior dorsal vertebrae, in which the spine is approximately

216 level with the SPOLs. Euhelopus and Mamenchisaurus both share this feature, but the anterior

217 dorsal neural spines of those taxa are bifid (Ouyang \& Ye, 2002; Wilson \& Upchurch, 2009). In 
219 2017), Tendaguria (Bonaparte, Heinrich \& Wild, 2000) and, to a lesser extent, Mierasaurus 220 (Royo-Torres et al., 2017a), strongly resemble that of NHMUK 1871. In contrast, the 221 anteriormost dorsal vertebrae of Turiasaurus have dorsoventrally taller neural spines (Royo-

222

223

224

225

226

227

228

229

230

231

232

233

234

235

236

237

238

239

240

241

242

243

244

245

246

247

248

249

250

251

252

253

254

255

256

257

258

259

260

261

262 Torres et al., 2006, 2017a).

In summary, the combination of: (1) a dorsoventrally compressed centrum; (2) the retention of prominent epipophyses; (3) the low, non-bifid neural spine; and (4) the overall morphology of NHMUK 1871, more closely resembles the anteriormost dorsal vertebrae of turiasaurs than any other sauropods (Fig. 3). In particular, NHMUK 1871 appears to be most similar to Moabosaurus and Tendaguria. The anterior and posterior surfaces of the diapophyses of NHMUK 1871 are unexcavated though, contrasting with those two taxa (Mannion et al., in press). Despite the incomplete and fragmentary nature of NHMUK 1871, it appears to be readily referable to Turiasauria, more closely related to Moabosaurus + Tendaguria than to other turiasaurs.

\section{Possible implications for turiasaurs from the Late Jurassic Tendaguru Formation of Tanzania}

Upchurch, Mannion \& Taylor (2015) recovered a sister taxon relationship between Janenschia and Haestasaurus (see also Mannion et al., in press), which are sympatric with Tendaguria and (probably) NHMUK 1871, respectively. Such close affinities might indicate a close faunal relationship between the latest Jurassic Tendaguru Formation and the Early Cretaceous Wealden Supergroup. Furthermore, this could conceivably be regarded as circumstantial evidence that Tendaguria is a junior synonym of Janenschia if NHMUK 1871 was recovered from the same area and stratigraphic bed as Haestasaurus. Given that both Janenschia and Tendaguria are recovered as turiasaurs in some of the phylogenetic analyses of Mannion et al. (in press), synonymy remains a possibility. However, until we find limb material associated with anterior dorsal vertebrae that can be referred to any of these taxa, such synonymisation cannot be justified.

\section{Turiasaurian sauropod biogeography and evolutionary history}

In addition to the named taxa Turiasaurus, Losillasaurus, Zby, Mierasaurus, Moabosaurus, and Tendaguria, several remains have been referred to Turiasauria (see Introduction). Most of these referrals are based on isolated teeth. Although the 'heart'-shape is quite distinctive in most of the referred western European teeth, this is not the case in all instances (e.g. the type specimen of Oplosaurus armatus, from the Early Cretaceous of the UK), and especially not for the African specimens (two of which preserve only half of the crown). Mocho et al. (2016) identified three morphotypes of putative turiasaur teeth, which they suggested could be explained in two ways: either they represent different taxa, potentially including nonturiasaurs, or they are indicative of variation along the tooth row. The North American turiasaurs Mierasaurus and Moabosaurus show a clear heterodont dentition (Britt et al., 2017; Royo-Torres et al., 2017a), with subtle heterdonty present in Turiasaurus too (Royo-Torres \& Upchurch, 2012). As such, the second hypothesis of Mocho et al. (2016) might well be correct. However, two of their morphotypes overlap with the teeth of other non-neosauropods (e.g. Jobaria; see also Mocho et al., 2016: fig. 7), and thus only broad, 'heart'-shaped teeth can 
263 currently be attributed to Turiasauria with confidence. As such, the isolated teeth from the 264 Middle Jurassic and Early Cretaceous of Africa cannot unambiguously be referred to 265 Turiasauria, and are herein regarded as indeterminate eusauropods.

266 Xing et al. (2015) recovered the Middle Jurassic Moroccan sauropod Atlasaurus as a 267 turiasaur in their phylogenetic analysis, but this result was not supported in recent studies that 268 scored turiasaurian taxa based on firsthand observations (Mannion, Allain \& Moine, 2017; 269 Royo-Torres et al. 2017a; Mannion et al., in press). Very little published information is currently 270 available for Atlasaurus, and it is in need of revision. As such, its phylogenetic affinities are

271

272

273

274

275

276

277

278

279

280

281

282

283

284

285

286

287

288

289

290

291

292

293

294

295

296

297

298

299

300

301

302

303

304

305

306 uncertain (see Mannion et al., in press), but there is currently no evidence to support a turiasaurian placement. Finally, Mannion et al. (in press) recovered two Late Jurassic taxa within Turiasauria that would greatly extend the group's distribution: the Argentinean sauropod Tehuelchesaurus, and the Chinese taxon Bellusaurus. However, those placements should be treated with caution: Tehuelchesaurus was placed outside of Turiasauria when extended implied weighting was applied, and Bellusaurus is known only from juvenile remains, which might affect its phylogenetic position (Moore et al., 2018). Furthermore, these positions have not been recovered in independent analyses (e.g. D'Emic, 2012; Royo-Torres \& Upchurch, 2012; Carballido et al., 2017).

In summary, there is currently only unequivocal evidence for Turiasauria in the late Middle Jurassic-Early Cretaceous of western Europe (UK, France, Spain and Portugal), the Late Jurassic of Tanzania, and the late Early Cretaceous of the USA, but other remains suggest the possibility that the clade was more widespread, at least in the Late Jurassic.

\section{CONCLUSIONS}

A previously undescribed anterior dorsal centrum and neural arch (NHMUK 1871) from the Early Cretaceous Wealden Supergroup of the UK is recognised as a turiasaurian eusauropod dinosaur. This material shares several synapomorphies with Turiasauria, especially the Late Jurassic Tanzanian sauropod Tendaguria, and Moabosaurus, from the Early Cretaceous of the USA. NHMUK 1871 represents the first postcranial evidence for Turiasauria from European deposits of unequivocal Early Cretaceous age. Unambiguous evidence for the non-neosauropod eusauropod clade Turiasauria is restricted to the late Middle Jurassic-Early Cretaceous of western Europe, the Late Jurassic of Tanzania, and the late Early Cretaceous of the USA, although remains from the Late Jurassic of Argentina and China might mean that the group had a near-global distribution.

\section{ACKNOWLEDGEMENTS}

I would like to express my gratitude to Paul Barrett and Susannah Maidment at the NHMUK for providing access to NHMUK 1871, as well as to all those who have facilitated the study of sauropod remains in their care. Comments from Rafael Royo-Torres also improved this manuscript.

\section{REFERENCES}


307 Bakker RT. 1977. Tetrapod mass extinctions-A model of the regulation of speciation rates and 308 immigration by cycles of topographic diversity. In: Hallam A, ed. Patterns of Evolution. 309 Amsterdam: Elsevier, 439-468.

310 Barco JL, Canudo JI, Cuenca-Bescós G. 2006. Descripción de las vértebras cervicales de 311 Galvesaurus herreroi Barco, Canudo, Cuenca-Bescós \& Ruiz-Omeñaca, 2005 (Dinosauria, 312 Sauropoda) del tránsito Jurásico-Cretácico en Galve (Teruel, España). Revista Española de 313 Paleontología 21:189-205.

314 Barrett PM, McGowan AJ, Page V. 2009. Dinosaur diversity and the rock record. Proceedings of 315 the Royal Society of London, Series B 276:2667-2674.

316 Batten DJ. 2011. English Wealden Fossils. London: Palaeontological Association, 769 pp.

317 Bonaparte JF, Heinrich W-D, Wild R. 2000. Review of Janenschia Wild, with the description of a 318 new sauropod from the Tendaguru beds of Tanzania and a discussion on the systematic value of procoelous caudal vertebrae in the Sauropoda. Palaeontographica, Abteilung A 256:25-76.

Britt BB, Scheetz RD, Whiting MF, Wilhite DR. 2017. Moabosaurus utahensis, n. gen., n. sp., a new sauropod from the Early Cretaceous (Aptian) of North America. Contributions from the Museum of Paleontology, University of Michigan 32:189-243.

Campos-Soto S, Cobos A, Caus E, Benito MI, Fernández-Labrador L, Suarez-Gonzalez P, Quijada IE, Mas R, Royo-Torres R, Alcalá L. 2017. Jurassic Coastal Park: A great diversity of palaeoenvironments for the dinosaurs of the Villar del Arzobispo Formation (Teruel, eastern Spain). Palaeogeography, Palaeoclimatology, Palaeoecology 458:154-177.

326

327

328

329

330

331

332

333

334

335

336

337

338

339

340

Carballido JL, Sander PM. 2014. Postcranial axial skeleton of Europasaurus holgeri (Dinosauria, Sauropoda) from the Upper Jurassic of Germany: implications for sauropod ontogeny and phylogenetic relationships of basal Macronaria. Journal of Systematic Palaeontology 12:335387.

Carballido JL, Rauhut OWM, Pol D, Salgado L. 2011. Osteology and phylogenetic relationships of Tehuelchesaurus benitezii (Dinosauria, Sauropoda) from the Upper Jurassic of Patagonia. Zoological Journal of the Linnean Society 163:605-662.

Carballido JL, Salgado L, Pol D, Canudo JI, Garrido A. 2012. A new basal rebbachisaurid (Sauropoda, Diplodocoidea) from the Early Cretaceous of the Neuquén Basin; evolution and biogeography of the group. Historical Biology 24:631-654.

Carballido JL, Pol D, Otero A, Cerda IA, Salgado L, Garrido AC, Ramezani J, Cúneo NR, Krause JM. 2017. A new giant titanosaur sheds light on body mass evolution among sauropod dinosaurs. Proceedings of the Royal Society of London, Series B 284:20171219.

D’Emic MD. 2012. The early evolution of titanosauriform sauropod dinosaurs. Zoological Journal of the Linnean Society 166:624-671.

D'Emic MD, Foreman BZ. 2012. The beginning of the sauropod dinosaur hiatus in North America: insights from the Lower Cretaceous Cloverly Formation of Wyoming. Journal of Vertebrate Paleontology 32:883-902.

D'Emic MD, Foster JR. 2016. The oldest Cretaceous North American sauropod dinosaur. Historical Biology 28:470-478.

Gallina PA, Apesteguía S, Haluza A, Canale JI. 2014. A diplodocid sauropod survivor from the Early Cretaceous of South America. PLoS ONE 9:e97128.

349 Gilmore CW. 1936. Osteology of Apatosaurus with special reference to specimens in the 350 Carnegie Museum. Memoirs of the Carnegie Museum 11:175-300. 
351 Hunt AP, Lockley MG, Lucas SG, Meyer CA. 1994. The global sauropod fossil record. GAIA $352 \quad 10: 261-279$.

353 Mannion PD, Upchurch P, Carrano MT, Barrett PM. 2011. Testing the effect of the rock record on diversity: a multidisciplinary approach to elucidating the generic richness of sauropodomorph dinosaurs through time. Biological Reviews 86:157-181.

Mannion PD, Upchurch P, Barnes RN, Mateus O. 2013. Osteology of the Late Jurassic Portuguese sauropod dinosaur Lusotitan atalaiensis (Macronaria) and the evolutionary history of basal titanosauriforms. Zoological Journal of the Linnean Society 168:98-206.

Mannion PD, Allain R, Moine 0. 2017. The earliest known titanosauriform sauropod dinosaur and the evolution of Brachiosauridae. PeerJ 5:e3217.

361

362

Mannion PD, Upchurch P, Schwarz D, Wings O. In press. Taxonomic affinities of the putative titanosaurs from the Late Jurassic Tendaguru Formation of Tanzania: phylogenetic and biogeographic implications for eusauropod dinosaur evolution. Zoological Journal of the Linnean Society (doi: 10.1093/zoolinnean/zly068).

Marsh OC. 1878. Principal characters of American Jurassic dinosaurs. Part I. American Journal of Science 16:411-416.

Mateus O, Mannion PD, Upchurch P. 2014. Zby atlanticus, a new turiasaurian sauropod (Dinosauria, Eusauropoda) from the Late Jurassic of Portugal. Journal of Vertebrate Paleontology 34:618-634.

McPhee BW, Mannion PD, de Klerk WJ, Choiniere JN. 2016. High diversity in the sauropod dinosaur fauna of the Lower Cretaceous Kirkwood Formation of South Africa: implications for the Jurassic-Cretaceous transition. Cretaceous Research 59:228-248.

373

Mocho P, Royo-Torres R, Ortega F. 2014. Phylogenetic reassessment of Lourinhasaurus alenquerensis, a basal Macronaria (Sauropoda) from the Upper Jurassic of Portugal. Zoological Journal of the Linnean Society 170:875-916.

375

376

Mocho, P, Royo-Torres R, Malafaia E, Escaso F, Silva B, Ortega F. 2016. Turiasauria-like teeth from the Upper Jurassic of the Lusitanian Basin, Portugal. Historical Biology 28:861-880.

Moore AJ, Mo J, Clark JM, Xu X. 2018. Cranial anatomy of Bellusaurus sui (Dinosauria: Eusauropoda) from the Middle-Late Jurassic Shishugou Formation of northwest China and a review of sauropod cranial ontogeny. PeerJ 6:e4881.

381

382

Néraudeau D, Allain R, Ballèvre M, Batten DJ, Buffetaut E, Colin JP, Dabard MP, DavieroGomez V, El Albani A, Gomez B, Grosheny D, Le Loeuff J, Leprince A, Martín-Closas C, Masure E, Mazin J-M, Phillipe M, Pouech J, Tong H, Tournepiche JF, Vullo R. 2012. The Hautevarian-Barremian lignitic bone bed of Angeac (Charente, south-west France): stratigraphical, palaeobiological and palaeogeographical implications. Cretaceous Research 37:1-14.

Osborn HF, Mook CC. 1921. Camarasaurus, Amphicoelias, and other sauropods of Cope. Memoirs of the American Museum of Natural History New Series 3:247-387.

389 Ouyang H, Ye Y. 2002. The first mamenchisaurian skeleton with complete skull: Mamenchisaurus youngi. Sichuan Science and Technology Press, Chengdu: 1-111.

392

Owen R. 1854. On some fossil reptilian and mammalian remains from the Purbecks. Quarterly Journal of the Geological Society 10:420-433. 
Poropat SF, Mannion PD, Upchurch P, Hocknull SA, Kear BP, Kundrát M, Tischler TT, Sloan T, Sinapius GHK, Elliott JA, Elliott DA. 2016. New Australian sauropods shed light on Cretaceous dinosaur palaeobiogeography. Scientific Reports 6:34467.

Royo-Torres R, Cobos A, Alcalá L. 2006. A giant European dinosaur and a new sauropod clade. Science 314:1925-1927.

Royo-Torres R, Cobos A. 2009. Turiasaur sauropods in the Tendaguru Beds of Tanzania. Journal of Vertebrate Paleontology 29 (supplement to no. 3):173A.

Royo-Torres R, Upchurch P. 2012. The cranial anatomy of the sauropod Turiasaurus riodevensis and implications for its phylogenetic relationships. Journal of Systematic Palaeontology 10:553-583.

402

403

404

Royo-Torres R, Cobos A, Luque L, Aberasturi A, Espílez E, Fierro I, González ANA, Mampel L, Alcalá L. 2009. High European sauropod dinosaur diversity during Jurassic-Cretaceous transition in Riodeva (Teruel, Spain). Palaeontology 52:1009-1027.

406

407

Royo-Torres R, Upchurch P, Mannion PD, Mas R, Cobos A, Gascó F, Alcalá L, Sanz JL. 2014. The anatomy, phylogenetic relationships and stratigraphic position of the Tithonian-Berriasian Spanish sauropod dinosaur Aragosaurus ischiaticus. Zoological Journal of the Linnean Society 171:623-655.

409

410

411

412

413

414

415

416

417

418

419

420

421

422

423

424

425

426

427

428

429

430

431

432

433

434

435

436

Royo-Torres R, Upchurch P, Kirkland JI, DeBlieux DD, Foster JR, Cobos A, Alcalá L. 2017a. Descendants of the Jurassic turiasaurs from Iberia found refuge in the Early Cretaceous of western USA. Scientific Reports 7:14311.

Royo-Torres R, Fuentes C, Meijide M, Meijide-Fuentes F, Meijide-Fuentes M. 2017b. A new Brachiosauridae Sauropod dinosaur from the lower Cretaceous of Europe (Soria Province, Spain). Cretaceous Research 80:38-55.

Tennant JP, Mannion PD, Upchurch P, Sutton MD, Price GD. 2017. Biotic and environmental dynamics across the Late Jurassic-Early Cretaceous transition: evidence for a protracted period of faunal and ecological turnover. Biological Reviews 92:776-814

Upchurch P. 1995. The evolutionary history of sauropod dinosaurs. Philosophical Transactions of the Royal Society of London, Series B 349:365-390.

Upchurch P, Barrett PM. 2005. A phylogenetic perspective on sauropod diversity. In: Curry Rogers K, Wilson JA, eds. The Sauropods: Evolution and Paleobiology. Berkeley: University of California Press, 104-124.

Upchurch P, Mannion PD, Taylor MP. 2015. The Anatomy and Phylogenetic Relationships of "Pelorosaurus" becklesii (Neosauropoda, Macronaria) from the Early Cretaceous of England. PLOS ONE 10:e0125819.

Wedel MJ. 2003. The evolution of vertebral pneumaticity in sauropod dinosaurs. Journal of Vertebrate Paleontology 23:344-357.

Wedel MJ. 2005. Postcranial skeletal pneumaticity in sauropods and its implications for mass estimates. In: Curry Rogers KA, Wilson JA, eds. The sauropods: evolution and paleobiology. Berkeley; Los Angeles: University of California Press, 201-228.

Wilson JA, Sereno PC. 1998. Early evolution and higher-level phylogeny of sauropod dinosaurs. Society of Vertebrate Paleontology Memoir 5:1-68.

Wilson JA, Upchurch P. 2009. Redescription and reassessment of the phylogenetic affinities of Euhelopus zdanskyi (Dinosauria: Sauropoda) from the Early Cretaceous of China. Journal of Systematic Palaeontology 7:199-239. 
437 Woodhams K. 1990. On the trail of Iguanodon. Proceedings of the Croyden Natural History and 438 Scientific Society 18:45-58.

439 Xing L, Miyashita T, Currie PJ, You H, Zhang J, Dong Z. 2015. A new basal eusauropod from the Middle Jurassic of Yunnan, China, and faunal compositions and transitions of Asian sauropodomorph dinosaurs. Acta Palaeontologica Polonica 60:145-154.

Yates AM. 2007. The first complete skull of the Triassic dinosaur Melanorosaurus Haughton (Sauropodomorpha: Anchisauria). Special Papers in Palaeontology 77:9-55.

Figure 1. Photographs of the anterior dorsal centum NHMUK 1871 in (A) anterior, (B) posterior, (C) left lateral, (D) right lateral, (E) dorsal, and (F) ventral views. Abbreviations: $A C D L$, anterior centrodiapophyseal lamina; CPOL, centropostzygapophyseal lamina; CPRL, centroprezygapophyseal lamina; Ipf, lateral pneumatic foramen; nc, neural canal; PCDL, posterior centrodiapophyseal lamina. Scale bar equals $100 \mathrm{~mm}$. Photographs taken by the author.

Figure 2. Photographs of the anterior dorsal neural arch NHMUK 1871 in (A) anterior, (B) posterior, (C) right lateral, and (D) dorsal views. Abbreviations: dia, diapophysis; epi, epipophysis; PCDL, posterior centrodiapophyseal lamina; PODL, postzygapophysis; poz, postzygapophysis; prz, prezygapophysis; SDF, spinodiapophyseal fossa; SPOL, spinopostzygapophyseal lamina; SPRL, spinoprezygapophyseal lamina; TPOL, interpostzygapophyseal lamina; TPRL, interprezygapophyseal lamina. Scale bar equals $200 \mathrm{~mm}$. Photographs taken by the author.

Figure 3. Comparative line drawings showing dorsal vertebra 2-3 in anterior view for an array of eusauropods: (A) NHMUK 1871 (centrum + arch); (B) the turiasaur Tendaguria tanzaniensis (after Mannion et al., in press); (C) the turiasaur Moabosaurus utahensis (after Britt et al., 2017); (D) the mamenchisaurid Mamenchisaurus youngi (after Ouyang \& Ye, 2002); (E) the diplodocid Apatosaurus louisae (after Gilmore, 1936); (F) the basal macronarian Camarasaurus supremus (after Osborn \& Mook, 1921; (G) the brachiosaurid Europasaurus holgeri (after Carballido \& Sander, 2014); and (H) the basal somphospondylan specimen known as the Cloverly titanosauriform (after D’Emic \& Foreman, 2012). Vertebrae partially reconstructed where incomplete and not drawn to scale relative to one another.

Table 1. Measurements of the anterior dorsal vertebra NHMUK 1871. All measurements in 471 millimetres. 


\section{Figure 1 (on next page)}

Photographs of the anterior dorsal centum NHMUK 1871.

(A) anterior, (B) posterior, (C) left lateral, (D) right lateral, (E) dorsal, and (F) ventral views. Abbreviations: ACDL, anterior centrodiapophyseal lamina; CPOL, centropostzygapophyseal lamina; CPRL, centroprezygapophyseal lamina; Ipf, lateral pneumatic foramen; nc, neural canal; PCDL, posterior centrodiapophyseal lamina. Scale bar equals $100 \mathrm{~mm}$. Photographs taken by the author. 

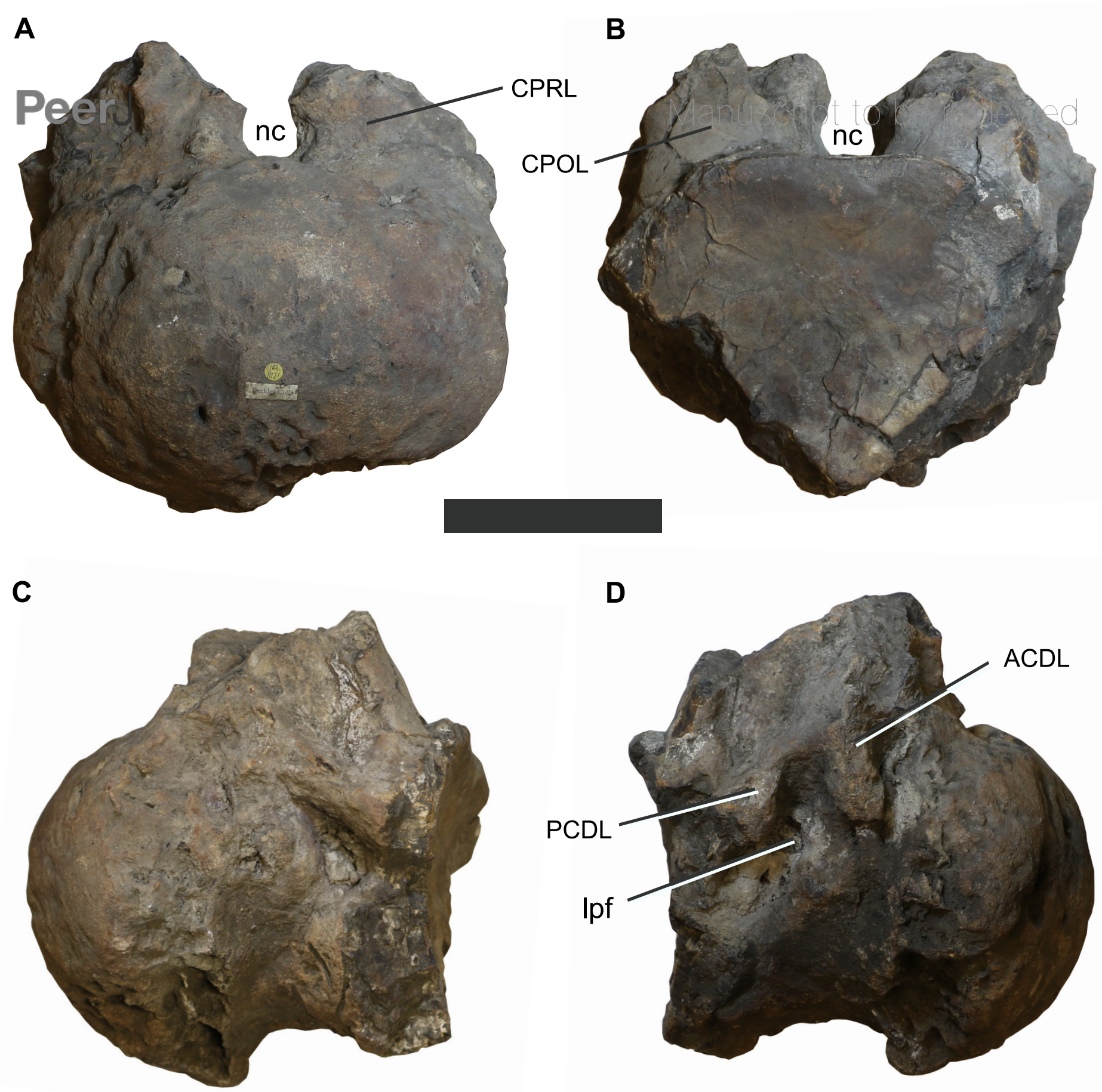

E

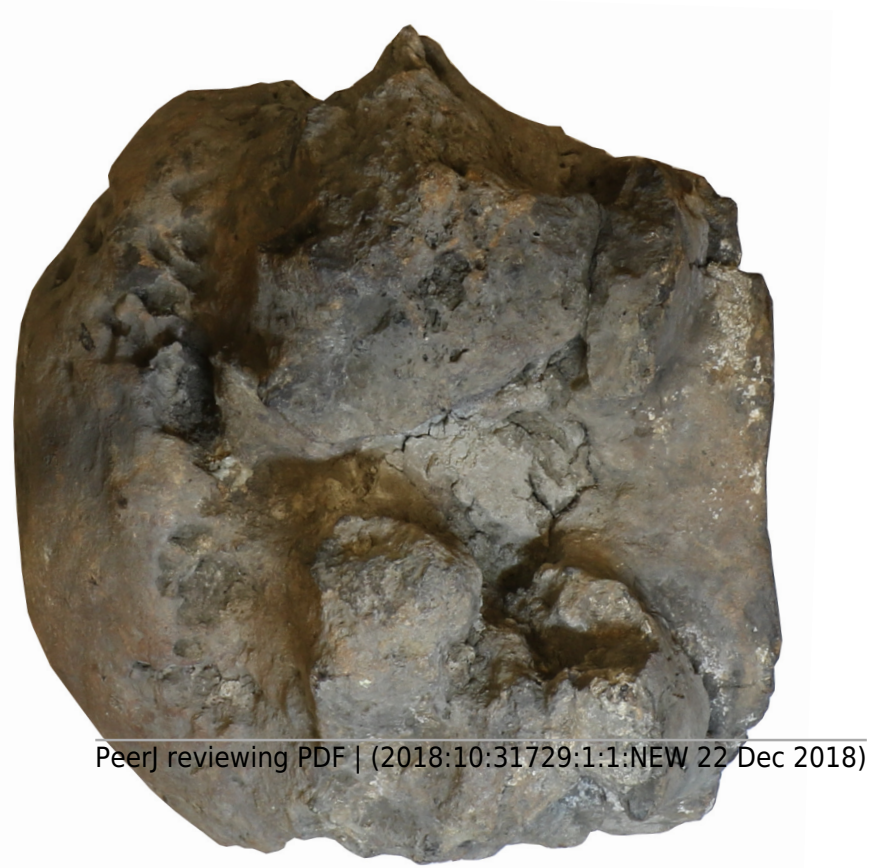

F

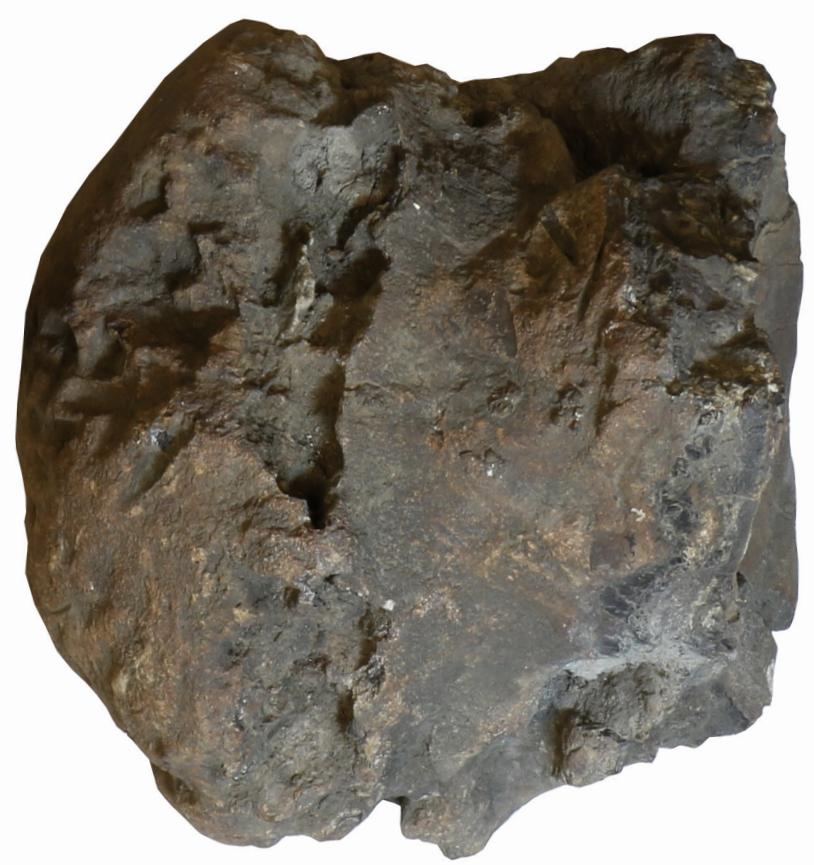




\section{Figure 2 (on next page)}

Photographs of the anterior dorsal neural arch NHMUK 1871.

(A) anterior, (B) posterior, (C) right lateral, and (D) dorsal views. Abbreviations: dia, diapophysis; epi, epipophysis; PCDL, posterior centrodiapophyseal lamina; PODL, postzygapophysis; poz, postzygapophysis; prz, prezygapophysis; SDF, spinodiapophyseal fossa; SPOL, spinopostzygapophyseal lamina; SPRL, spinoprezygapophyseal lamina; TPOL, interpostzygapophyseal lamina; TPRL, interprezygapophyseal lamina. Scale bar equals 200 $\mathrm{mm}$. Photographs taken by the author. 


\section{Figure $\mathbf{3}$ (on next page)}

Comparative line drawings of anterior dorsal vertebrae of eusauropods

Comparative line drawings showing dorsal vertebra 2-3 in anterior view for an array of eusauropods: (A) NHMUK 1871 (centrum + arch); (B) the turiasaur Tendaguria tanzaniensis (after Mannion et al., in press); (C) the turiasaur Moabosaurus utahensis (after Britt et al., 2017); (D) the mamenchisaurid Mamenchisaurus youngi (after Ouyang \& Ye, 2002); (E) the diplodocid Apatosaurus louisae (after Gilmore, 1936); (F) the basal macronarian Camarasaurus supremus (after Osborn \& Mook, 1921; (G) the brachiosaurid Europasaurus holgeri (after Carballido \& Sander, 2014); and (H) the basal somphospondylan specimen known as the Cloverly titanosauriform (after D'Emic \& Foreman, 2012). Vertebrae partially reconstructed where incomplete and not drawn to scale relative to one another. 


\section{Table $\mathbf{1}$ (on next page)}

Measurements of the anterior dorsal vertebra NHMUK 1871.

All measurements in millimetres. 
1 Table 1. Measurements of the anterior dorsal vertebra NHMUK 1871. All measurements in 2 millimetres.

3

Dimension

Centrum length (including condyle)

Centrum length (excluding condyle)

Anterior centrum dorsoventral height

Anterior centrum mediolateral width

Total preserved dorsoventral height of neural arch and spine

Neural arch height

Transverse width from midline to distal tip of right diapophysis
Measurement

229

170

158

228

205

167

248

4

5 